\title{
Intra Regional Foreign Direct Investment (FDI) Prospect in South Asian Association of Regional Cooperation (SAARC) Region
}

\author{
M Sayeed Alam (corresponding author) \\ Assistant Professor \\ Dept of Business Administration, East West University (www.ewubd.edu) \\ 43, Mohakhali, Dhaka-1212, BANGLADESH \\ E-mail: sbl.dhk@gmail.com \\ Mahmud Zubayer \\ Assistant Professor \\ Dept of Business Administration, East West University (www.ewubd.edu) \\ 43, Mohakhali, Dhaka-1212, BANGLADESH
}

\begin{abstract}
The empirical literature offers regional integration arrangements reduce trade costs among partner countries this reduction in cost not only increase trade but also act as a stimulus to increase FDI flow. South Asian Association for Regional Cooperation (SAARC) was established in $8^{\text {th }}$ December 1985 with the seven South Asian countries (Bangladesh, Bhutan, India, Maldives, Nepal, Pakistan and Sri Lanka) but after 25 years of its establishment very low level of intra regional trade ( less than 5\%) and in case of FDI the major source is outward flow than intra regional flow. Despite the major difference among the member countries in different macro economic parameter there is a scope of potential for intra regional FDI inflow. In this study different research papers was presented with respect to regional trade and integration was studies. The major focus is on SAARC economic integration and FDI status. The study one other economic integration areas and FDI inflow was suggested for future research.
\end{abstract}

Keywords: Foreign direct investment, Intra regional FDI, SAARC

\section{Introduction}

Foreign direct investment combines aspects of both international trade in goods and international financial flows, and is a phenomena more complex than either of these. As its name suggests, it first involves ownership of the assets of a firm: foreign direct investment (FDI) is often defined as the acquisition of 10\% or more of the assets of a foreign enterprise. Second, it involves the choice of a host country for these assets. The decision of where to invest will depend on cost conditions and the extent to which investment gives preferential access to the local market, and both of these considerations depend on trade restrictions and other policies in the host country. In this respect, the decision of firms to invest abroad will be a counterpart to the international trade policies of the countries involved. Third, FDI involves the decision of which activities to keep internal to a firm, and which to contract on the market: only the activities internal to a firm will be included in FDI, while other activities can be pursued by arms-length transactions between unrelated firms (Feenstra, 1998). Alam Jahangir, and A.F.M Aowrangazab. mentioned Agrawal (2005) comprehensive study which has been done to evaluate the economic impact of FDI in South Asia where he took Bangladesh as one of the sample-countries of his study. He found that the impact of FDI inflows on GDP growth rate was negative prior to 1980, mildly positive for early eighties and strongly positive over the late eighties and early nineties, supporting the view that FDI is more likely to be beneficial in more open economies. He also found that since 1980, FDI inflows contributed more to GDP growth in South Asia than did an equal amount of foreign borrowing. This suggests that FDI is preferable to foreign borrowing.

\section{About South Asian Association for Regional Cooperation (SAARC)}

The heads of Seven South Asian Countries of SAARC (Bangladeshi, Bhutan, India, Maldives, Nepal, Pakistan and Sri Lanka) signed the charter to establish the South Asian Association for Regional Cooperation (SAARC) on December $8^{\text {th }}$, 1985.Afghanistan joined SAARC as a Member at the Fourteenth SAARC Summit, Delhi, April 2007. SAARC is unique concept of regional cooperation. with very distinct geographical, cultural, environmental diversity, the SAARC member states compress of the worlds highest mountains, land locked mountains terrains to deltaic low line flood - prone areas and one of the smallest low line island nation in the 
world.With the world's most populous country, SAARC is home to nearly 1.5 billion people or about $22 \%$ of world's population (http://www.saarc-sec.org/Charter-Day/6/)

\section{Regional integration and FDI:}

Most of the South Asian countries have undertaken far-reaching economic reforms: they have adopted industrial policies that encourage foreign direct investment (FDI) resulting in an increase in FDI flows. However, the amount of inflows attracted by the regions remains relative to East Asia and South East Asia quite insignificant. In 1998, it was US\$ 3.43 billion, a mere 0.5 percent of global flows. In contrast, China received more than 10 percent of global inflows. By 2002 although total FDI flows to South Asia had increased to US\$ 4.58 billion, this was still well below 1 percent of global FDI inflows. Paper titled "Foreign Direct Investment And Economic Integration In The SAARC Region", presented at the Second Conference of the South Asia Network of Economic Research Institutes (SANEI) to be held in Kathmandu on August 28-29 2000, Institute of Policy Studies of Sri Lanka Colombo mentioned that Regional integration typically reduces barriers to trade in goods as well as investment among members; sometimes, as in the case of EU, it also reduces barriers to labour mobility. The impact of regional integration arrangements (RIAs) on trade differ from those associated with across the board reductions in barriers to trade, and have been analysed in a large literature with the reference of Hine, R. C. (1994) Samaratunga, R.H.S. (1999). In this paper it is mentioned that RIAs can change the level and pattern of FDI, and thereby affect trade in ways that are not fully captured in standard trade theoretic analyses of customs unions. Trade and investment liberalisation will change the location specific and firm-specific advantages. RIAs, for example, can encourage geographical concentration: MNEs can restructure their production bases to take advantage of reduced trade costs while exploiting scale economies and agglomeration advantages. This may lead to FDI outflows from countries that had earlier attracted 'tariff hopping' foreign firms to service protected domestic markets because they can now be competitively supplied from production bases elsewhere. On the other hand, better access to a larger market may attract FDI (from within the region as well as from outside) to countries that have a strong locational advantage. Such locational advantages may arise from availability of cheaper resources, superior infrastructure, political stability, a more favourable policy regime, and a host of other factors. Market size of three devolving country regions are shown in the following

NAFTA, market size is 11400 , where its is 548 for ASEAN and for SAARC it is 605 , all figures are in US\$ bn, an the year 2001 (Source: WTO and WDI, use from paper the Dirk Willem te Velde and Dirk Bezemer, "Regional Integration and Foreign Direct Investment in Developing Countries" July 2004, This paper forms part of a larger DFID/EC-PREP funded research project on Regional Integration and Poverty)

The main objectives of this paper are

\section{To learn about the FDI status in SAARC countries}

\section{Prospects of intra regional FDI in this region}

\section{FDI in developing economy: Theories and present situation}

Until the 1980s, most developing countries viewed Foreign Direct Investment (FDI)1 with great suspicion (Robin A. Iftekhar). Bosworth and Collins (1999) conducted comprehensive study concerning the effect of capital inflows on domestic investment for 58 developing countries during 1978-95 (Razin Assaf, 2002). Bosworth and Collins (1999) distinguish among three types of inflows: FDI, portfolio investment, and other financial flows (primarily bank loans). Bosworth and Collins (1999) find that an increase of a dollar in capital inflows is associated with an increase in domestic investment of about 50 cents. (Both capital inflows and domestic investment are expressed as percentages of GDP.) These results hold both for the 58-country sample and for a subset of 18 emerging markets (Razin Assaf, 2002). Bosworth and Collins (1999) said about a striking feature of FDI flows is that the share of FDI in total inflows is higher in riskier countries, as measured either by countries' credit ratings for sovereign (government) debt or other indicators of country risk. There is also some evidence that the FDI share is higher in countries where the quality of corporate governance institutions is lower (Razin Assaf, 2002). But from the late 90's inter-country competition to attract scarce FDI is becoming increasingly intense as host country governments seek to exploit to the full the potential advantages of increased linkages with the globalizing economy (Jones, 2000). Most of the developing governments now adopt a positive stand towards FDI, seeing it increasingly as a means of improving the competitiveness of their indigenous resources and capabilities. In Bangladesh total FDI inflows was gradually increase over the years. In 1972, annual FDI inflow of Bangladesh was 0.090 million USD (UNCTAD 2005), but after 33 years, in 2005 annual FDI rose to 845.30 million USD. 
(Enterprise Survey conducted by the Bangladesh Bank.). If we look at the word statistics the scenario is changing. The total FDI inflow to the developed economics was 71.8 billion in $1983-88$, which was $78.4 \%$ of the total inflow (UN World Investment report 1995, 1996, Annex, Table 1-2), during that time developing economy constituted $21.6 \%$ of the total FDI .inflow (Table-I). But now it is we recognized the benefit of FDI inflow. In the year 1995 developing economics constitute $31.6 \%$ of the total FDI inflow. 1988 to 1995, within 7 years the growth in FDI inflow is $10 \%$ more.

\section{FDI situation Bangladesh and other SAARC countries}

FDI to the SAARC region is predominantly from outside the region. The sectors that have attracted most foreign investment vary between countries. In the case of Bangladesh, and Sri Lanka, the textile and garment sectors account for 28 percent and 16 percent respectively of FDI, whereas 56 percent of FDI has gone into infrastructure projects in India. In the case of Pakistan, 40 percent of all FDI has gone into the power sector. While FDI from outside the regions has been far greater than intra-regional investments, there are signs that intra-regional investments are increasing. The major inward FDI flows are from Indian firms, which have started to expand FDI both within South Asia and beyond. Firms from other South Asian countries are also increasingly undertaking FDI within the region and investing in a wide range of sectors and activities.

There are two SAARC countries, Nepal and Bhutan, where FDI from India is the predominant source of FDI. On the other hand, none of the SAARC countries are significant investors in Pakistan though there is a very limited FDI flow from other countries in the region. India is the largest investors among the SAARC countries in the Sri Lanka, while Pakistan and Maldives are respectively second and third to India as investors. In the case of Bangladesh, firms from India, Pakistan and Sri Lanka have in recent years invested US\$ 418 million in 133 ventures covering a wide range of sectors. In spite of India's huge internal market, investment from other SAARC countries have been quite insignificant, both in relative and absolute terms, accounting for less than one 9 per percent of total foreign investment in India. Bangladesh is the largest investors in India from the region, followed by Sri Lanka, Nepal and Maldives (Alam Jahangir, and A.F.M Aowrangazab. 2005). Findings from the study conducted by the Institute of Policy Studies of Sri Lanka Colombo on "Foreign Direct Investment And Economic Integration In The SAARC Region", ( this paper was presented at the Second Conference of the South Asia Network of Economic Research Institutes (SANEI) in Kathmandu on August 28-29 2000 showed that Until recently, most countries in South Asia have not been seen by international investors as attractive investment destinations and, in any case did not welcome foreign investments. Hence, until the 1990s, FDI flows were quite minimal. The (Portfolio investments were even smaller, given capital account restrictions and undeveloped financial markets.) FDI flows to South Asia started to pick up in the mid-1990s largely as a result of progressive liberalisation of FDI policies in most of the countries in the region, and the adoption of generally more outward oriented policies. According to this findings the share of FDI in SAARC region are shown in the table -II. Though GDP growth rate of Bangladesh is higher but FDI inflow is not consistent with this growth rate. it is seen that there is a decline in FDI inflow rate (6.24\%) in Bangladesh where as with poor GDP growth rate Pakistan FDI inflow rate is increases $136 \%$, India is the highest recipient of FDI inflow among the SAARC countries followed by Pakistan. Bhutan and Nepal are the worst condition in FDI inflow condition. (Table: III).

In Bangladesh the FDI is classified as 1. Equity Capital, 2. Reinvested Earnings 3. Intra-company Loans. The major portion of the FDI is coming from the equity capital. The plot shows that there is no stable trend is present in any categories. Instead of trend some randomness is present in the FDI data. (Table-IV, Figure-I).

Findings from the study conducted by the Institute of Policy Studies of Sri Lanka Colombo on "Foreign Direct Investment And Economic Integration In The SAARC Region", (this paper was presented at the Second Conference of the South Asia Network of Economic Research Institutes (SANEI) in Kathmandu on August 28-29 2000 showed that the present quite low level of intra-regional trade in SAARC (less than $5 \%$ of total trade) is partly a result of policy. Countries in SAARC share some basic similarities (low income, relatively labour abundant etc., comparative advantage in similar commodities, such as tea) reduce the potential for comparative advantage driven trade. The low per capita income level also constrains potential for intra-industry trade, generally associated with higher income countries. 15 On the other hand, the existence of significant relative differences among the SAARC countries should not be forgotten. India dominates other countries in terms of size. In comparison, most others are much smaller. Sri Lanka has a relatively more educated workforce than others, and also has relatively higher per capita income and wage levels. The potential for expanding intra-SAARC economic links, in both trade and investment, is not entirely absent. 


\section{Doing business variables in SAARC region}

The major challenges Bangladesh is facing is inflation rate and boost business confidence to attract more FDI. Inflation accelerated compared to the past years with rises price of the food and non food items. The global ranking on starting a business and protecting investors, Bangladesh position is 68 (World Bank, 2007, this cover 7 resign and 175 countries. The lower the ranking the better the performance). Where as Maldives, Nepal, Pakistan and Sri Lanka's position is above Bangladesh India is behind Bangladesh (Ranking 88). Bangladesh is also lagging behind for its poor infrastructure .According to Competitiveness index ranking Bangladesh position is 120 (Global Competitiveness Report of the World Economic Forum (WEF), quality of infrastructure (WEF 2007). Ranking is based on 131 countries).

India had the best ranking in the region at 67, followed closely by Pakistan (72) and Sri Lanka (73). All these put Bangladesh in a backward position to attract FDI compared to India and Pakistan.

In case starting a business Bangladesh position is better than India. But In Bangladesh it will take at least 74 days to start a business where as the numbers in India is only 33. Bangladesh is worst case to start a business with respect to time in days. (Table $-\mathrm{V}$ ). On the other hand to get licensee the number of days required is almost same in Bangladesh, India and Pakistan, (Table-VI).

Profit tax is second highest in Bangladesh (30.3\%) in SAARC region. On the other hand there is no labor tax for Bangladesh (Table-VII).

\section{FDI inflow by sector a comparison between Bangladesh, India and Pakistan}

The major sector of FDI inflow in Bangladesh is Telecommunication, Power gas and Petroleum, Manufacturing, Trade and commerce. If we look at the major sector of India and Pakistan then telecommunication is the common among Bangladesh, India and Pakistan. Both Bangladesh India and Pakistan service sector FDI inflow is maximum, (telecommunication sector is considered as a service sector). In India the biggest sector in FDI inflow is service (In 2006, 5270 million \$ dollar) and in Pakistan it is the second largest (In $2007=3086$ million $\$$ dollar) (Table-VIII). But for the three countries the major FDI inflow is in service sector (In Bangladesh $60.0 \%$ FDI inflow in service sector. In India it is 51\% and in Pakistan 66\%, based on 2006 data for Bangladesh and India and 2007 data for Pakistan).

\section{The leading source of Countries of FDI: The Intra regional FDI inflow}

In Bangladesh the leading source country in FDI inflow is UK ( $\$ 175.71$ million dollar followed by USA 105.36, Singapore 88.02, UAE 82.96 Norway 70.48 based on 2007 Bangladesh Bank data). In case of India the sequence is Mauritius (\$6363 million followed by UK (1878), USA (856), Netherlands (644), Singapore (578). In case of Pakistan the leading countries in FDI are UK (\$ 1820 million) then USA (1767), Netherlands (778), Peoples Republic of China (712) and UAE (677). But Intra regional FDI flow is almost absent. (Table- IX).

But if we look at the case of Bulgaria the major FDI inflow from its regional developed economics, Like Germany 50.21\%, The Netherlands (18.83\%), UK (12.34\%), Switzerland (7.67\%) (Glaister, 1998).

In South Asia there is no developed economy but if the intra regional FDI inflow will be promoted it will be a starting point for united South Asia and in future this region will be as strong as EU and ASEAN. Regional cooperation should be vigorously promoted. Policies to facilitate cross-border trade and investment are also required to promote FDI regionally. It is important to note that intra-regional FDI in South Asia remains small compared to the levels in other Asian regions. India stands almost alone as an investor in its regional neighbors. Measures to encourage investment from India in other South Asian countries may help promote regional cooperation.

FDI flows between East Asia and Southeast Asia have been significant. However, within East Asia, there is a relatively high level of intra-regional FDI, due mainly to the presence of the Peoples Republic of China, an attractive destination for foreign investment. On the other hand, cross-border FDI within South Asia is negligible (Ahmed and Ghani 2007).

\section{Conclusion}

In SAARC FDI from outside is more important than in intra regional investment in most countries (the only exception is Nepal, where Indian investments dominate. The concept of some regions can be applicable to increase intra regional FDI, there are some regions (ANDEAN, ASEAN, MERCOSUR) have cooperation schemes which aim to establish regional enterprises by promoting joint ventures. The ASEAN region seems to be one of the most advanced in this area. The ASEAN Industrial Cooperation scheme (AICO Scheme) seeks to promote joint manufacturing industrial activities between ASEAN-based companies. More than 100 projects have been selected for special tax and tariff incentives (Dirk Willem te Velde and Dirk Bezemer (2004). 
Blomstrom and Kokko (1997) also in favor of regional integration lead to efficiency gains and higher growth, and thus further FDI. FDI can actually be such a catalyst through spillovers in terms of technology transfer and other linkages with local firms. According to Mehta (2007) though growth in FDI inflows slow but South Asia has witnessed much greater expansion in its share in Global and Asian FDI stocks due to sharp rise in India's share. Rising value of FDI stocks would be a potential source of inwards FDI mainly in the form of cross boarder M\&A especially from those MNCs which operate with the motive to seek already created productive assets. Rapidly expanding South Asian market would be a main attractive force for FDI inflows. Through more intra regional cooperation can reduce the infrastructure deficit and addressing the energy requirements of the region (Ahmed and Ghani 2007). Cross-border infrastructure supply systems, such as power, road, and telecommunication networks, are promising for regional cooperation and for the promotion of both FDI and intra regional FDI. If regional cooperation and harmonization in policy between the countries, it will not only receive more FDI , regional investment opportunities will act as a gate way to make this region a future economic power like Peoples Republic of China.

\section{References}

Ahmed, Sadiq, and Ejaz Ghani, eds. (2007). South Asia Growth and Regional Integration. Washington DC: World Bank.

Alam Jahangir, A.F.M Aowrangazab. (2005) • "Intra-Regional Foreign Direct Investment- The South Asian Perspective"

Agrawal , Pradeep (2000) : Economic Impact of Foreign Direct Investment in South Asia, Working Paper, Indira Gandhi Institute of Development Research, India.

Barry P. Bosworth and Susan M. Collins. (1999). "Capital Flows to Developing Economies: Implications for Saving and Investment," Brookings Papers on Economic Activity: 1, Brookings Institution, pp. 143-69.

Blomström, M. and A. Kokko. (1997) "Regional Integration and Foreign Direct Investment, NBER Working Paper 6019.

Coase, R.H. (1937). "The nature of the firm", Economica, Vol. 4, pp. 386-405. Evers, B. and Kirkpatrick, C. (1990), "Review article: new forms of foreign investment in developing countries", Journal of International Development, Vol. 2 No. 3, pp. 407-22. Greene,

Dirk Willem te Velde and Dirk Bezemer. (2004), "Regional Integration and Foreign Direct Investment in Developing Countries" This paper forms part of a larger DFID/EC-PREP funded research project on Regional Integration and Poverty

Feenstra C. Robert. (1998). "Facts and Fallacies about Foreign Direct Investment", Dept. of Economics, University of California, Davis,Haas School of Business, Univ. of California, Berkeley,and National Bureau of Economic Research,Revised, December.

Glaister W. Keith and Atanasova Hristina. (1998). "Foreign Investment in Bulgaria: Patterns and Prospects" European Business Review, Volume-98, Number-2, PP-122-134.

Hine, R. C. (1994) 'International Economic Integration', in Greenaway, D. and Winters, L. A. (eds) Surveys in International Trade, Blackwell Publishers, Oxford.

Jalilian H. (1996). "Foreign investment location in less developed countries: a theoretical framework" Journal of Economic Studies, Vol-23, No-4, PP-18-30.

Jones Alam, Fallon Grahame, Golov Roman. (2000). "Obstacles to foreign direct investment in Russia", European Business Review, Volume 12, Number-4, pp-187-197.

Mehta Sanjeev. (2007). "Inwards FDI to South Asia: Identifying the Driver" SAARC Journal of Human Resource Development

Razin Assaf. (2002). "FDI Flows and Domestic Investment: Overview” Prepared For CES-Ifo Studies July $1^{\text {st }}$.

Robin A. Iftekhar. "Foreign Direct investment: impact on sect oral growth in Bangladesh" PP-181-191

Sobhan, Rehman. (2004). Promoting Cooperation in South Asia - An Agenda for the 13 th SAARC Summit, Promoting and Facilitating Investment in South Asia, Edited, The University Press Limited, Dhaka, Bangladesh.

South Asia Economic Report. (2007). "Foreign Direct Investment in South Asia" Published by Asian Development Bank, December.

Samaratunga, R.H.S. (1999) Essays in trade policy and economic integration with special reference to South Asia, Unpublished Ph.D thesis, La Trobe University, Melbourne. 
Table-I. FDI inflow (Developed and Developing Economy)

FDI Inflows (\$Billion):

\begin{tabular}{lcrrrrrrr}
\hline Host region/economy & $1983-88^{*}$ & 1989 & 1990 & 1991 & 1992 & 1993 & 1994 & 1995 \\
Total inflows & 91.6 & 200.6 & 203.8 & 157.8 & 168.1 & 207.9 & 225.7 & 314.9 \\
\hline Developed Economies & 71.8 & 171.7 & 169.8 & 114.0 & 114.0 & 129.3 & 132.8 & 203.2 \\
Developed Share as \% of total & $\mathbf{7 8 . 4 \%}$ & $\mathbf{8 5 . 7 \%}$ & $\mathbf{8 3 . 4 \%}$ & $\mathbf{7 3 . 8 \%}$ & $\mathbf{7 0 . 0} \%$ & $\mathbf{6 4 . 8 \%}$ & $\mathbf{6 1 . 4 \%}$ & $\mathbf{6 8 . 4 \%}$ \\
\hline Developing economies & 19.8 & 28.6 & 33.7 & 41.3 & 50.4 & 73.1 & 87.0 & 99.7 \\
Developing Share as \% of total & $\mathbf{2 1 . 6 \%}$ & $\mathbf{1 4 . 3 \%}$ & $\mathbf{1 6 . 6 \%}$ & $\mathbf{2 6 . 2 \%}$ & $\mathbf{3 0 . 0} \%$ & $\mathbf{3 5 . 2 \%}$ & $\mathbf{3 8 . 6 \%}$ & $\mathbf{3 1 . 6 \%}$ \\
\hline
\end{tabular}

Source: Feenstra, 1998

Table -II. Share of SAARC in FDI Inflows (percentage)

\begin{tabular}{|c|c|c|c|c|}
\hline & $\mathbf{1 9 8 0 - 8 5}$ & $\mathbf{1 9 9 0}$ & $\mathbf{1 9 9 5}$ & $\mathbf{1 9 9 8}$ \\
\hline World & 0.36 & 0.23 & 0.83 & 0.53 \\
\hline Developing Countries & 1.42 & 1.46 & 2.61 & 2.07 \\
\hline Asia & 3.55 & 2.42 & 4.09 & 4.04 \\
\hline
\end{tabular}

Table-III. Net FDI inflows for SARRC countries

\begin{tabular}{|c|c|c|c|c|}
\hline & \multicolumn{2}{|c|}{ FDI ( \$ million) } & \multirow[t]{2}{*}{$\begin{array}{c}\text { Annual growth } \\
(\%) \\
\end{array}$} & \multirow[t]{2}{*}{$\begin{array}{l}\text { Share of Regional FDI total (\%) } \\
\text { ( based on } 2006 \text { data) }\end{array}$} \\
\hline & 2005 & 2006 & & \\
\hline Bangladesh & 845.3 & 792.5 & $(6.24)$ & 3.27 \\
\hline Bhutan & 9 & 6 & $(32.2)$ & 0.0 \\
\hline India & 7,661 & 19,442 & 153.8 & 79.9 \\
\hline Maldives & 10 & 14 & 46.3 & 0.1 \\
\hline Nepal & 2 & (6) & (441.6) & 0.0 \\
\hline Pakistan & 1459 & 3451 & 136.5 & 14.2 \\
\hline Sri Lanka & 234 & 451 & 92.7 & 1.9 \\
\hline
\end{tabular}

Source: Asian Development Bank (South Asia Economic Report, December, 2007), Bangladesh data from Enterprise Survey conducted by Bangladesh Bank.

Table-IV. Breakdown of Bangladesh FDI data

\begin{tabular}{|c|c|c|c|c|c|c|}
\hline & 2001 & 2002 & 2003 & 2004 & 2005 & 2006 \\
\hline Total FDI inflows & 354.5 & 328.3 & 350.2 & 460.4 & 845.3 & 792.5 \\
\hline Equity Capital & 233.8 & 133.8 & 156.1 & 155.9 & 425.6 & 503.6 \\
\hline Reinvested earnings & 65.0 & 116.8 & 170.1 & 239.8 & 247.5 & 264.7 \\
\hline Intra-company Loans & 55.7 & 77.7 & 24.0 & 64.7 & 172.2 & 24.1 \\
\hline
\end{tabular}

Source: Enterprise Survey conducted by

Bangladesh Bank

Table-V. Starting a business

\begin{tabular}{|l|l|l|l|}
\hline Country & $\begin{array}{l}\text { Rank } \\
\mathbf{2 0 0 8}(\mathbf{2 0 0 7})\end{array}$ & $\begin{array}{l}\text { Numbers of Procedure 2008 } \\
(\mathbf{2 0 0 7})\end{array}$ & Time in days 2008 (2007) \\
\hline Bangladesh & $102(107)$ & $8(8)$ & $74(50)$ \\
\hline Bhutan & $122(119)$ & $8(10)$ & $48(62)$ \\
\hline India & $120(132)$ & $13(11)$ & $33(35)$ \\
\hline Maldives & $60(58)$ & $5(5)$ & $9(9)$ \\
\hline Nepal & $111(104)$ & $7(7)$ & $31(31)$ \\
\hline Pakistan & $76(73)$ & $11(11)$ & $24(24)$ \\
\hline Sri Lanka & $101(100)$ & $5(8)$ & $39(50)$ \\
\hline
\end{tabular}


Table-VI. Dealing with license

\begin{tabular}{|l|l|l|l|l|}
\hline Country & Rank 2008 (2007) & Numbers of Procedure 2008 (2007) & Time in days 2008 (2007) & Cost (\% of income per capita) \\
\hline Bangladesh & $102(107)$ & $14(14)$ & $252(252)$ & $751(875.4)$ \\
\hline Bhutan & $122(119)$ & $25(25)$ & $183(183)$ & $195.9(309.8)$ \\
\hline India & $120(132)$ & $20(20)$ & $224(224)$ & $519.4(606)$ \\
\hline Maldives & $60(58)$ & $9(9)$ & $118(118)$ & $39.9(44.8)$ \\
\hline Nepal & $111(104)$ & $15(15)$ & $424(424)$ & $304.7(324)$ \\
\hline Pakistan & $76(73)$ & $12(12)$ & $223(223)$ & $869.5(972.9)$ \\
\hline Sri Lanka & $101(100)$ & $22(22)$ & $214(214)$ & $1921(2192)$ \\
\hline
\end{tabular}

Table-VII. Tax rate

\begin{tabular}{|l|l|l|l|l|}
\hline Country & Rank 2008 (2007) & Profit tax (\%) 2008 & Labor tax and contributions (\%) 2008 & Other taxes (\%) 2008 \\
\hline Bangladesh & $102(107)$ & 30.3 & 0 & 9.2 \\
\hline Bhutan & $122(119)$ & 34.2 & 1.1 & 4.4 \\
\hline India & $120(132)$ & 19.6 & 18.4 & 32.5 \\
\hline Maldives & $60(58)$ & 0 & 0 & 9.1 \\
\hline Nepal & $111(104)$ & 20 & 11.3 & 1.3 \\
\hline Pakistan & $76(73)$ & 25.8 & 12.6 & 2.3 \\
\hline Sri Lanka & $101(100)$ & 26.5 & 16.9 & 20.4 \\
\hline
\end{tabular}

Source: Table V, VI, VII is http://www.doingbusiness.org

Table - VIII. FDI inflow by Sector in Bangladesh, India and Pakistan (\$ million)

\begin{tabular}{|c|c|c|c|c|}
\hline Bangladesh & 2004 & 2005 & \multicolumn{2}{|c|}{2006} \\
\hline Telecommunication & 127.50 & 281.95 & \multicolumn{2}{|c|}{346.91} \\
\hline Power Gas and Petroleum & 124.05 & 208.25 & \multicolumn{2}{|c|}{208.25} \\
\hline Manufacturing & 139.46 & 219.28 & \multicolumn{2}{|c|}{104.86} \\
\hline Trade and commerce & 66.59 & 130.49 & \multicolumn{2}{|c|}{130.23} \\
\hline Agriculture & 1.73 & 2.32 & \multicolumn{2}{|c|}{1.26} \\
\hline and Fishing & & & & \\
\hline Services & 1.08 & 2.99 & \multicolumn{2}{|c|}{0.25} \\
\hline OTHERS & 0.00 & 0.00 & \multicolumn{2}{|c|}{0.72} \\
\hline India & 2004 & 2005 & \multicolumn{2}{|c|}{2006} \\
\hline Cement and Gypsum Products & 0 & 452 & \multicolumn{2}{|c|}{243} \\
\hline Chemicals & 198 & 447 & \multicolumn{2}{|c|}{206} \\
\hline Construction & 152 & 151 & \multicolumn{2}{|c|}{985} \\
\hline Drugs and Pharmaceuticals & 292 & 172 & \multicolumn{2}{|c|}{215} \\
\hline Electrical Equipment & 721 & 1,451 & \multicolumn{2}{|c|}{2,733} \\
\hline Fuel & 166 & 94 & \multicolumn{2}{|c|}{250} \\
\hline Food Processing & 38 & 42 & \multicolumn{2}{|c|}{98} \\
\hline Services Sector & 469 & 581 & \multicolumn{2}{|c|}{4,749} \\
\hline Telecommunications & 129 & 680 & \multicolumn{2}{|c|}{521} \\
\hline Transportation & 179 & 222 & \multicolumn{2}{|c|}{466} \\
\hline Pakistan & \multicolumn{2}{|c|}{2005} & \multicolumn{2}{|l|}{2006} \\
\hline Communications & \multicolumn{2}{|c|}{518} & \multicolumn{2}{|l|}{1,938} \\
\hline Financial Business & \multicolumn{2}{|c|}{269} & \multicolumn{2}{|l|}{329} \\
\hline Oil and Gas Explorations & \multicolumn{2}{|c|}{194} & \multicolumn{2}{|l|}{313} \\
\hline Tobacco and Cigarettes & \multicolumn{2}{|c|}{7} & \multicolumn{2}{|r|}{390} \\
\hline Power & \multicolumn{2}{|c|}{73} & \multicolumn{2}{|l|}{321} \\
\hline Trade & & & 118 & 173 \\
\hline Construction & & & 90 & 157 \\
\hline Petroleum Refining & & & 31 & 155 \\
\hline Beverages & & & 6 & 89 \\
\hline Personal Services & & & 62 & 84 \\
\hline
\end{tabular}

Source: Bangladesh: Enterprise Survey conducted by the Bangladesh Bank.

India and Pakistan: ADB report on FDI-2008 
Table-IX. Intra-Regional FDI in South Asia (\% of total regional FDI inflows)

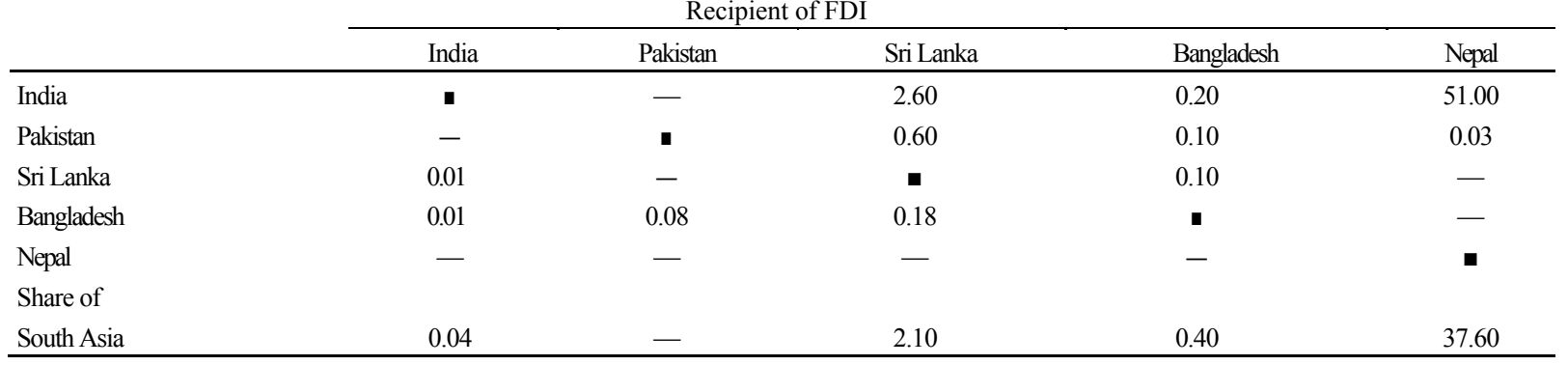

Source: Bhattacharya, Debapriya. 2007. South Asia: Intra-Regional Opportunities and Challenges. Presented at the Fostering Trade through Private-Public Dialogue Expert Meeting on Regional Integration in Asia, New Delhi, 28-29 March; other sources and time periods.

ADB report on South Asia Economic Report "Foreign direct Investment in South Asia", 2008

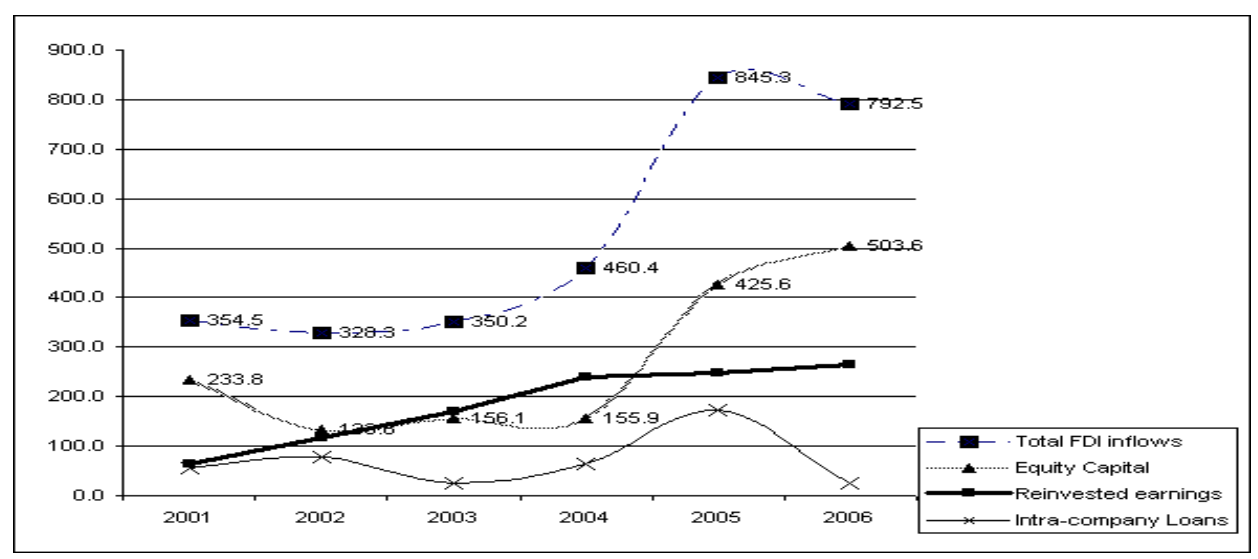

Figure I. Trend of FDI in Bangladesh 